\title{
Nowe oraz zmodernizowane uklady i zespoły w modernizowanej lokomotywie spalinowej typu 303D serii SU46
}

\begin{abstract}
Artykut jest poświęcony prezentacji nowych i zmodernizowanych układów i zespotów zastosowanych $w$ modernizowanej lokomotywie spalinowej serii SU46 (303D) przeznaczonej docelowo do prowadzenia pociagów towarowych w ruchu transgranicznym pomiędzy Polska i Niemcami. $W$ artykule przedstawiono główne parametry lokomotywy przed i po modernizacji oraz ogólne opisy nowych i zmodernizowanych układów i zespolów. Ponadto zaprezentowano zakres przewidywanych prób $i$ badań (stacjonarnych, ruchowych, eksploatacyjnych) niezbędnych dla uzyskania przez lokomotywe świadectwa dopuszczenia do eksploatacji typu pojazdu kolejowego. Artykut powstat w ramach realizowanego projektu celowego $\mathrm{nr} 6 \mathrm{ZR}$ $2009 C / 07187$ p. n. „Zmodernizowana lokomotywa spalinowa serii SU46 przystosowana do wymagań TSI obowiazujacych w Unii Europejskiej" wykonywanego wspólnie przez Instytut Pojazdów Szynowych „,TABOR” w Poznaniu i Pojazdami Szynowymi „PESA” Bydgoszcz Spółka Akcyjna Holding.
\end{abstract}

\section{Wstęp}

Wymagania stawiane obecnie pojazdom trakcji spalinowej wymuszają na przewoźnikach państwowych (PKP Cargo, ICC, Przewozy Regionalne) oraz na prywatnych operatorach kolejowych i kolejach regionalnych pozyskiwanie nowych lokomotyw oraz modernizację posiadanego i eksploatowanego taboru.

Związane jest to przede wszystkim z ograniczeniami szkodliwego oddziaływania wykorzystanych silników spalinowych oraz zmniejszeniem jednostkowego zużycia oleju napędowego. W związku z tym, że wielu użytkowników nie stać na zakup nowoczesnych lokomotyw spalinowych za granica, a polski przemysł produkujacy takie lokomotywy w zasadzie nie istnieje, pozostaje realizacja procesu modernizacji lokomotyw będących w eksploatacji.

Należy również zaznaczyć, że proces modernizacji lokomotyw spalinowych wynika $\mathrm{z}$ następujących przesłanek [3]:

- nadążenie za postępującym rozwojem technicznym

- spełnienie wymagań rynkowych w zakresie utrzymania i eksploatacji

- równowaga pomiędzy poziomem technicznym lokomotyw posiadanych i nowych

- wyższe wymagania maszynistów i obsługi serwisowej w stosunku do lokomotyw starszych wiekiem.

Cele jakie stawia się w pracach projektowo-wdrożeniowych oczekiwane przez użytkowników w stosunku do modernizowanych lokomotyw spalinowych to [4]:
- zmniejszenie zużycia oleju napędowego i środków smarnych

- ograniczenie szkodliwego oddziaływania na środowisko naturalne w tym zmniejszenie emisji do atmosfery składników toksycznych spalin takich $\mathrm{CO}, \mathrm{HC}, \mathrm{NO}_{\mathrm{x}}$ i cząstki stałe

- zmniejszenie wydzielania $\mathrm{CO}_{2}$ do atmosfery

- zwiększenie przebiegów eksploatacyjnych pomiędzy wykonywanymi przeglądami i naprawami oraz przetoczeniami obręczy

- zastosowanie nowoczesnych i trwałych aparatów, urządzeń i elementów o wydłużonym czasie eksploatacji.

Ponadto $\mathrm{w}$ prowadzonych modernizacjach stawia się na ograniczenie emisji hałasu wewnętrznego i pola magnetycznego w kabinach sterowniczych oraz poprawę komfortu obsługi i bezpieczeństwa w kabinach w wyniku zastosowania nowoczesnych układów pulpit-fotel, stosowania klimatyzacji oraz poprawę widoczności sygnałów ze stanowiska sterowniczego. Od połowy lat 80-tych prowadzone były częściowe prace modernizacyjne a w zasadzie kosmetyczne, przy czym dokonywano również procesu „remotoryzacji” polegającego $\mathrm{w}$ zasadzie na wymianie przestarzałych silników spalinowych. Wśród typowych lokomotyw spalinowych przeznaczonych przede wszystkim do ruchu liniowego - prowadzenie pociagów towarowych - najważniejsze modernizacje to $[1,2,3,4,5$, 6]:

- modernizacja lokomotywy ST44 wykonana przez Bumar-Fablok Chrzanów na potrzeby 
PKP LHS i Pol-Miedź-Trans

- modernizacja lokomotywy M62 wykonana przez Rail Polska - Włosienica na potrzeby własne

- modernizacja lokomotywy ST44 (311D) wykonana przez Newag - Nowy Sącz dla PKP LHS i DB-Schenker

- modernizacja lokomotywy ST44 wykonana przez PESA Bydgoszcz dla PKP Cargo, PKP LHS i Pol-Miedź-Trans.

W pierwszych trzech przypadkach moc lokomotywy została zwiększona o połowę, natomiast w czwartym przypadku wymieniony silnik na nowocześniejszy posiadał identyczną moc tak więc moc lokomotywy nie uległa zmianie.

Należy nadmienić, że modernizacji podlegały również spalinowe lokomotywy manewrowe które zostały wyposażane $\mathrm{w}$ dodatkowe układy i urządzenia gwarantujące pełne bezpieczeństwo podczas ruchu na torach Polskich Linii Kolejowych i były przeznaczane do prowadzenia pociagów pasażerskich i towarowych. $\mathrm{W}$ ostatnich dwóch latach poddano modernizacji pierwszą lokomotywę liniową produkcji polskiej SU45 (przekształconą na ST45) - wykonaną przez IPS „Tabor” Poznań i Pesa Bydgoszcz [5, 6]. Dotychczas z przewidywanych 20 lokomotyw wykonano tylko cztery zmodernizowane lokomotywy eksploatowane z powodzeniem przez PKP Cargo . Obecnie Instytut Pojazdów Szynowych wspólnie z Pesa Bydgoszcz realizuje projekt modernizacyjny spalinowej lokomotywy typu 303D serii SU46.

Projekt lokomotywy zakłada zmianę przeznaczenia lokomotywy z uniwersalnej na towarową oraz przystosowanie jej do wymagań TSI (techniczna specyfikacja interoperacyjności) obowiązujących w Unii Europejskiej.

Lokomotywy typu 303D serii SU46 były produkowane w latach 1974-1977 przez Fabrykę W3 HCP Poznań (obecnie FPS). Była to pierwsza krajowa lokomotywa przystosowana do elektrycznego ogrzewania wagonów w systemie $3 \mathrm{kV}$, które zapewniała prądnica prądu przemiennego o mocy $440 \mathrm{~kW}$. Ogółem wyprodukowano 54 szt. lokomotyw, przy czym dwie ostatnie o nr 053 i 054 powstały dopiero w 1985 r. po zaprzestaniu produkcji w 1977 w wyniku poleceń politycznych.

Obecnie $\mathrm{w}$ eksploatacji w ruchu pasażerskim i towarowym znajduje się około 30 szt. lokomotyw serii SU46.

\section{Parametry techniczne oracharakterystyka trak- cyjna lokomotywy}

Modernizowana spalinowa lokomotywa serii SU46 (ST46) po rezygnacji z funkcji ogrzewania składu pociagu przeznaczona zostanie zasadniczo do prowadzenia pociagów towarowych z prędkościami do 100 $\mathrm{km} / \mathrm{h}$ [7]. Oczekiwane przez przyszłego użytkownika możliwości trakcyjne do spełnienia przez zmodernizowaną lokomotywę to [7]:

- prowadzenie pociagu pasażerskiego o masie 430 ton na pochyleniu $0 \%$ z prędkością $100 \mathrm{~km} / \mathrm{h}$

- prowadzenie pociagu towarowego o masie 1700 ton na pochyleniu $0 \%$ z prędkością $80 \mathrm{~km} / \mathrm{h}$

- prowadzenie pociagu towarowego o masie 1500 ton na pochyleniu $3 \%$ z prędkością $60 \mathrm{~km} / \mathrm{h}$

- ruszanie z pociagiem o masie brutto 1500 ton na pochyleniu $10 \%$

przy zachowaniu wartości oporów ruchu dla lokomotywy zmodernizowanej nie większych od oporów dla lokomotywy przed modernizacja.

Głównymi celami prowadzonej modernizacji oczekiwanymi przez przyszłego użytkownika będzie poprawa parametrów technicznych i eksploatacyjnych lokomotyw.

Widok lokomotywy przed modernizacją przedstawiono na rys.1, a przewidywany wygląd po modernizacji przedstawiono na rys. 2. Wyznaczone charakterystyki lokomotywy prezentuje rys. 3 .
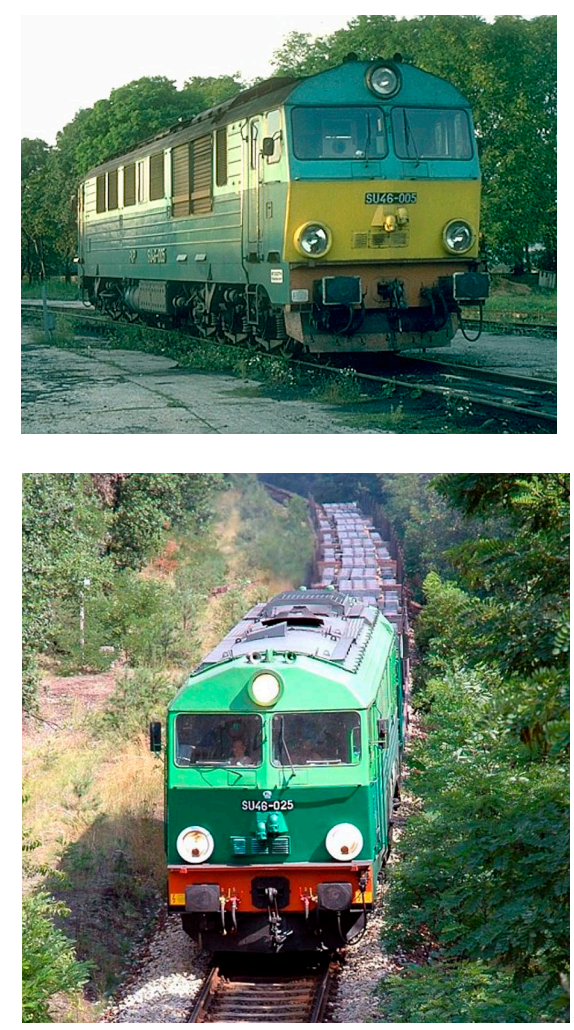

Rys. 1 - Widok lokomotywy SU46 przed modernizacją

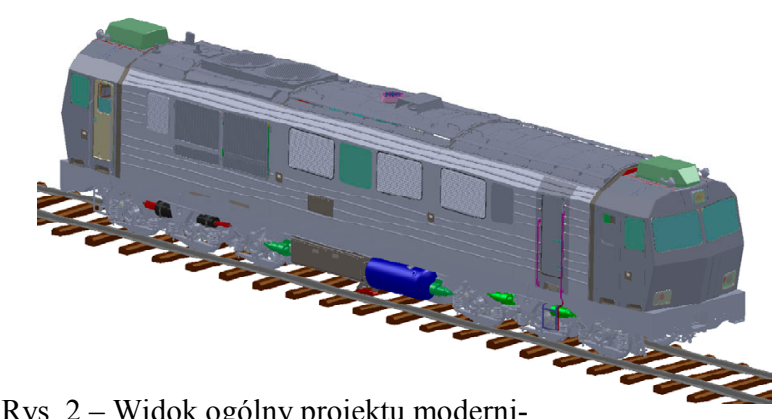

Rys. 2 - Widok ogólny projektu modernizowanej lokomotywy ST46 (303Da) 
a)

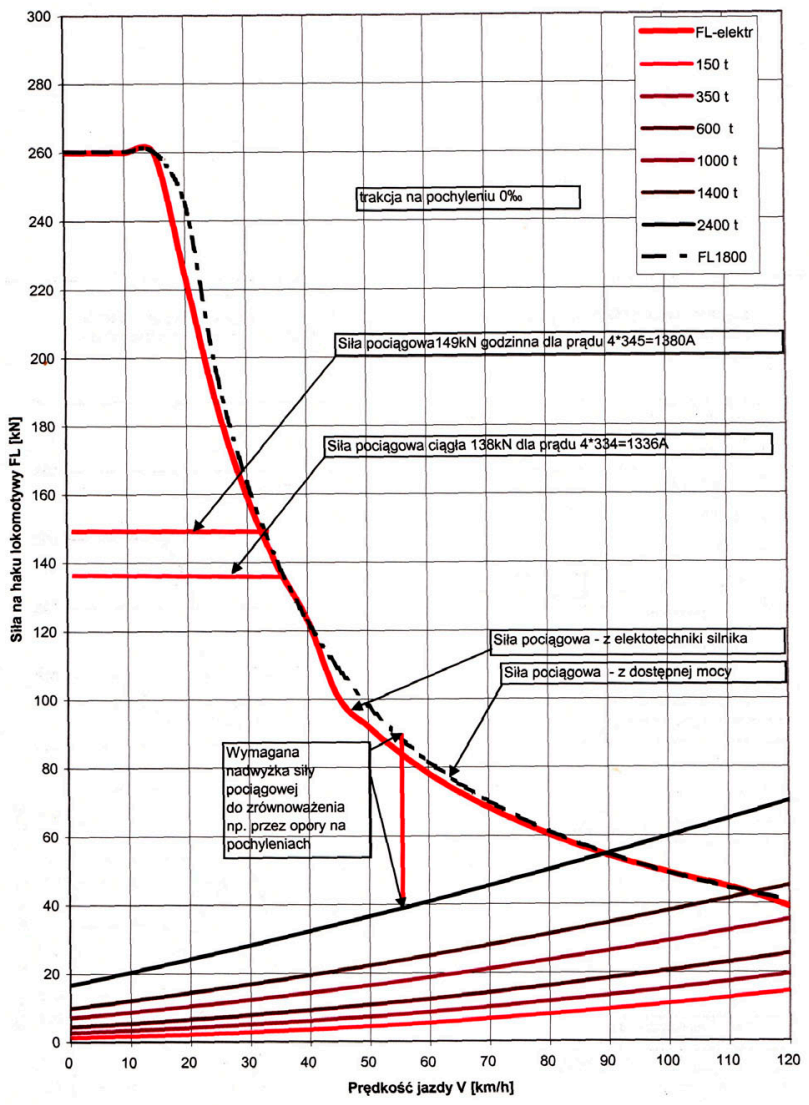

b)

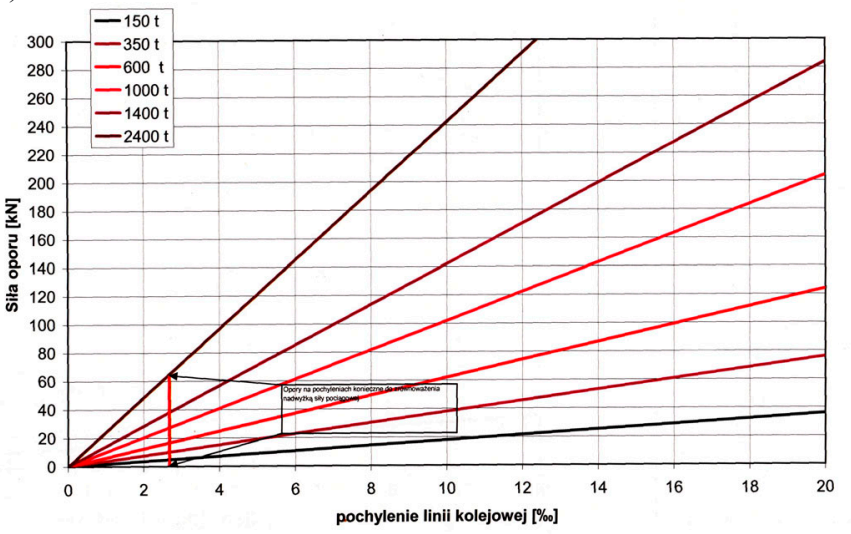

Rys. 3 - Charakterystyki zmodernizowanej lokomotywy ST46 (303Da) a - charakterystyka pociagowa; b- opory ruchu

Podstawowe parametry lokomotywy przed i po modernizacji przedstawiono w tabeli 1.
Parametry lokomotywy SU46 (ST46) przed i po modernizacji)

Tabela 1

\begin{tabular}{|c|c|c|c|c|}
\hline \multirow{2}{*}{ L.p. } & \multirow{2}{*}{ Nazwa parametru lub wielkość } & \multirow{2}{*}{ Jednostka } & \multicolumn{2}{|c|}{ Wartość parametru lub wielkość } \\
\hline & & & przed modernizacją & po modernizacji \\
\hline 1 & Oznaczenie lokomotywy & - & SU46 (303D) & ST46 (303Da) \\
\hline 2 & Szerokość toru & $\mathrm{mm}$ & \multicolumn{2}{|c|}{1435} \\
\hline 3 & Układ osi & - & \multicolumn{2}{|c|}{$\mathrm{Co}-\mathrm{Co}$} \\
\hline 4 & Prędkość max. & $\mathrm{km} / \mathrm{h}$ & \multicolumn{2}{|c|}{120} \\
\hline 5 & Masa służbowa & $\mathrm{Mg}$ & 102 & $\leq 104$ \\
\hline 6 & $\begin{array}{l}\text { Nacisk nominalny zestawu kołowego } \\
\text { na tor }\end{array}$ & $\mathrm{kN}$ & 170 & $\leq 170$ \\
\hline 7 & Przekładnia- & - & elektryczna DC/DC & elektryczna AC/DC \\
\hline 8 & Max. siła pociagowa & $\mathrm{kN}$ & $\begin{array}{l}317 \\
\text { przy } \psi=0,33\end{array}$ & $\begin{array}{c}260 \\
\operatorname{przy} \psi=0,26\end{array}$ \\
\hline 9 & Moc lokomotywy & $\mathrm{kW}$ & 1650 & 1800 \\
\hline 10 & Typ silnika spalinowego & - & W2112SSF & $12 \mathrm{~V} 4000 \mathrm{R} 43 \mathrm{~L}$ \\
\hline 11 & Typ prądnicy głównej & - & $\begin{array}{l}\text { GP846B1 } \\
\text { prądu stałego }\end{array}$ & $\begin{array}{l}\text { synchroniczna } \\
\text { firmy Lechmotoren }\end{array}$ \\
\hline 12 & Typ i moc prądnicy pomocniczej & - & $\begin{array}{l}\text { PCMOf106X } \\
\text { prądu stałego }\end{array}$ & $\begin{array}{l}\text { synchroniczna } \\
\text { firmy Lechmotoren }\end{array}$ \\
\hline 13 & Typ silnika trakcyjnego & - & \multicolumn{2}{|c|}{ LSM 493216} \\
\hline 14 & Prędkościomierz & - & $\begin{array}{l}\text { mechaniczny } \\
\text { RT9 i A16 }\end{array}$ & $\begin{array}{l}\text { elektrycznyEFA15 } \\
\text { firmy „Deute Werke” }\end{array}$ \\
\hline 15 & System sterowania & - & oporowy & $\begin{array}{l}\text { elektroniczny } \\
\text { mikroprocesorowy }\end{array}$ \\
\hline 16 & Typ i wydatek sprężarki powietrza & $\mathrm{m}^{3} / \mathrm{h}$ & $\begin{array}{l}\text { tłokowa } \\
\text { V2.15.8G, } 190\end{array}$ & $\begin{array}{l}\text { Śrubowa } \\
\text { Atlas Capco } 240\end{array}$ \\
\hline 17 & Napęd wentylatorów silników trakcyjnych & - & $\begin{array}{l}\text { elektryczny silnik prądu } \\
\text { stałego }\end{array}$ & $\begin{array}{c}\text { elektryczny silnik prądu } \\
\text { zmiennego }\end{array}$ \\
\hline 18 & Układ smarowania obrzeży kół & - & olejowe & olejowe firmy Rebs \\
\hline 19 & Stała instalacja gasząca & - & gazowe na halon & $\begin{array}{l}\text { firmy Fogtec na mgłe } \\
\text { wodną }\end{array}$ \\
\hline
\end{tabular}


3. Ogólny opis projektu modernizacyjnego lokomotywy i przewidzianych do zabudowy nowych i zmodernizowanych urządzeń, zespołów i ukladów

Zakres modernizacji wynikający przede wszystkim z wymagań techniczno-eksploatacyjnych przyszłego użytkownika dotyczył [8]:

- wymiany silnika spalinowego

- wprowadzenie zespołu prądnic synchronicznych (głównej i pomocniczej)

- przygotowania miejsca pod prądnice grzewczą

- zastosowania aparatów i urządzeń obwodów elektrycznych pomocniczych na napięcia $3 \times 400 \mathrm{~V}, 230$ V $50 \mathrm{~Hz}$ AC oraz $24 \mathrm{~V} \mathrm{DC} \mathrm{z}$ wykorzystaniem przetwornicy statycznej

- wprowadzenia napędów pomocniczych (sprężarki, wentylatorów, silników trakcyjnych, wentylatorów głównych chłodnicy) z wykorzystaniem silników prądu zmiennego i silników hydraulicznych

- rekonstrukcji układu pneumatycznego i hamulca poprzez zastosowanie tablicy pneumatycznej, hamulca postojowego, sprężynowego, układu przeciwpoślizgowego, sprężarki powietrza typu śrubowego

- zabudowy nowych podpór gumowo-metalowych, rekonstrukcji prowadzenia zestawu w ramie wózka, zabudowy układu smarowania obrzeży kół oraz układu podgrzewania cieczy chłodzącej

- wprowadzenia mikroprocesorowego układu sterowania i diagnostyki

- rekonstrukcji kabin sterowniczych w zakresie poprawy ergonomii i mikroklimatu

- zastosowania układów bezpieczeństwa ruchu stosowanych w Polsce i w Niemczech

- zmiany okien czołowych, likwidacji drzwi od strony maszynisty, zabudowy nowych lamp sygnałowych i oświetlenia zewnętrznego
- zastosowania elektronicznych prędkościomierzy, systemów radiołączności - polskiego i niemieckiego, urządzeń przeciwporażeniowych i przeciwpożarowych oraz układów pomiaru zużycia oleju napędowego

- wydłużenia przebiegów międzyprzeglądowych i międzynaprawczych oraz wzrost współczynnika gotowości technicznej.

Po zrealizowanej modernizacji lokomotywa SU46 zostanie nadal lokomotywą dwukabinową o układzie Co-Co i prędkości maksymalnej $120 \mathrm{~km} / \mathrm{h}$.

Przewidywane rozmieszczenie maszyn i urządzeń w zmodernizowanej lokomotywie przedstawiono na rys. 4 .

W projekcie modernizacji lokomotywy zamierza się wprowadzić następujące lub zmodernizowane urządzenia, podzespoły, zespoły i układy:

- zespól prądotwórczy tworzyć będą

- nowoczesny silnik spalinowy typu MTU 12V 4000 R43L (w miejsce silnika W 2112 SSF produkowanego na licencji Fiata) o mocy $1800 \mathrm{~kW}$ i zużyciu jednostkowym paliwa poniżej $210 \mathrm{~g} / \mathrm{kWh}$. Silnik odpowiada wymaganiom ujętym w Rozporządzeniu Ministra Gospodarki i Pracy (Dz. U. nr 202 poz. $1681 \mathrm{z}$ dnia 19.08 .2005 ), a ponadto cechuje się dużą niezawodnością, małym zużyciem środków smarnych, a zawartość

Rys.4 Ogólne rozmieszczenie głównych maszyn i urządzeń w modernizowanej lokomotywieST46 (303 Da)

1- zespół prądotwórczy; 2- akumulatory; 3- tłumik wylotu spalin; 4- filtry powietrza; 5 - zbiorniki główne powietrza; 6 - zbiorniki pomocnicze powietrza; 7- tablica pneumatyczna; 8 - sprężarka, 9szafa WN/SN; 10-szafa NN1; 11- szafa NN2; 12- szafa sterująca; 13- kanał wentylacji zespołu prądnic; 14- piasecznice; 15- wentylator silników trakcyjnych; 16- szafka odzieżowa i umywalka; 17 układ wodny umywalki; 18- układ p-poż; 19-klimatyzator; 20wentylator przedziału silnikowego; 21- zespół chłodnic; 22zbiornik płynu chłodzącego; 23- układ hydrostatyczny

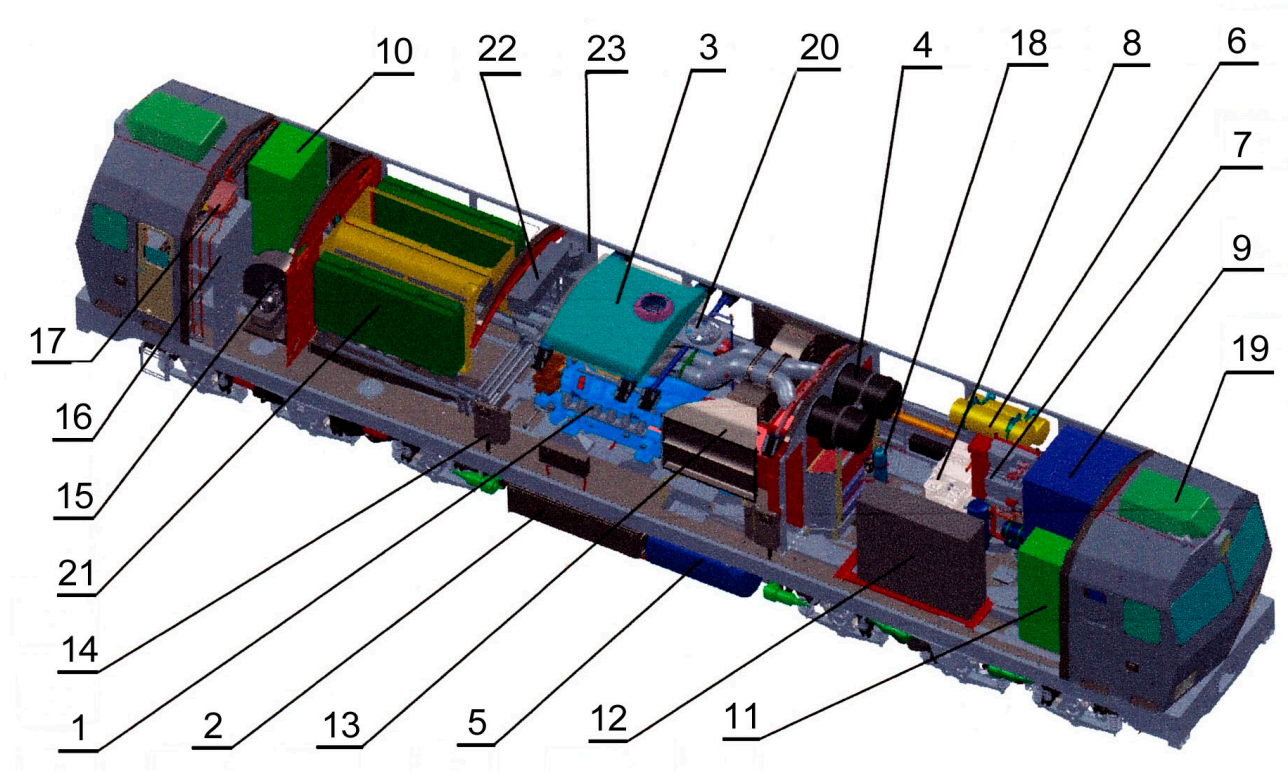


składników toksycznych do atmosfery odpowiada poziomowi IIIA wg dyrektywy 2004/26/WE.

Proponowany silnik wymusza zabudowę nowych układów wylotu spalin, chłodzenia, napędu wentylatorów chłodnic, ujęcia powietrza do silnika, układu doprowadzenia oleju napędowego oraz zastosowania nowych chłodnic i zbiornika wyrównawczego. Proponowany widok agregatu prądotwórczego przedstawiono na rys. 5 .

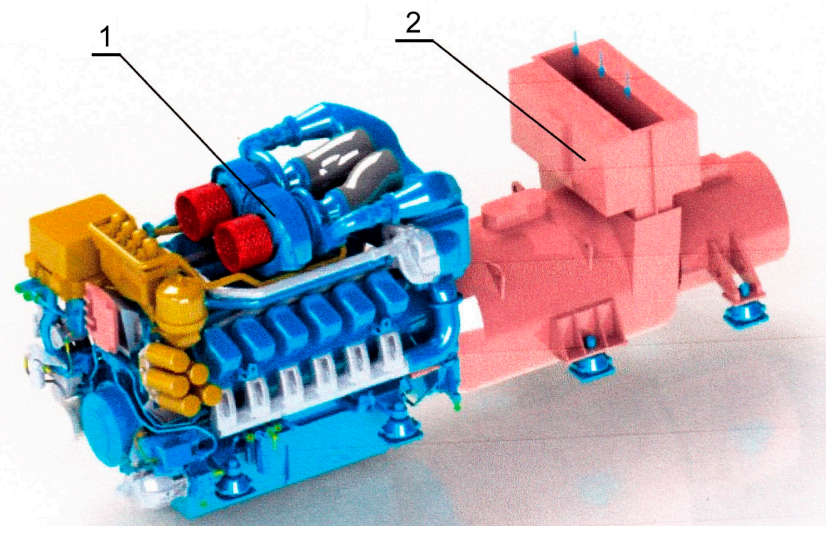

Rys. 5 - Widok ogólny agregatu prądotwórczego lokomotywy typu 303Da(ST46)

1- silnik spalinowy MTU; 2- zespół prądnic LECHMOTOREN

- zespół prądnic synchroniczych, główna bezszczotkowa o mocy około $1500 \mathrm{~kW}$ i pomocnicza o mocy $100 \mathrm{~kW}$. Prądnica główna będzie połączona kołnierzowo $\mathrm{z}$ silnikiem spalinowym

- napędy pomocnicze sprężarki i wentylatorów silników trakcyjnych realizować będą asynchroniczne silniki zasilane $\mathrm{z}$ przetwornic statycznych. Przetwornice zasilać będą również schładzacze dachowe, nagrzewnice, ogrzewanie szyb i kuchenkę elektryczną a ponadto służyć będą do zasilania układów sterowania, ładowania akumulatorów i oświetlenia

- obwody pomocnicze zasilane będą napięciami $3 x 400 \mathrm{~V}$ i $230 \mathrm{~V} 50 \mathrm{~Hz}$ AC oraz $110 \mathrm{~V}$ i $24 \mathrm{~V}$ DC, dla których źródłem będzie prądnica pomocnicza oraz zespół przetwornic statycznych

- układy sterowania i diagnostyki realizowane będą przez sterowniki mikroprocesorowe, manipulatory i układy zabudowane w szafie. Lokomotywa będzie mogła pracować pojedynczo oraz w trakcji wielokrotnej.

- uklad pneumatyczny i uklad hamulca wyposażony $\mathrm{w}$ tablicę pneumatyczną, zespół manipulatorów pulpitowych, hamulec postojowy typu sprężynowego oraz nowoczesną sprężarkę śrubową
- układ prowadzenia środkowego zestawów kołowych w ramie wózka oraz wprowadzenie dodatkowych podpór elastycznych wózka gwarantować będzie pełne bezpieczeństwo ruchu zarówno na torach PKP PLK jak i DB. Ponadto zestawy kołowe zostaną wyposażone w olejowy system smarowania obrzeży kół, a zlikwidowany zostanie sprzęg międzywózkowy. Ogólne rozmieszczenie głównych (dodatkowych) podzespołów na wózku lokomotywy ST46 (303Da) przedstawione na rys. 6 .

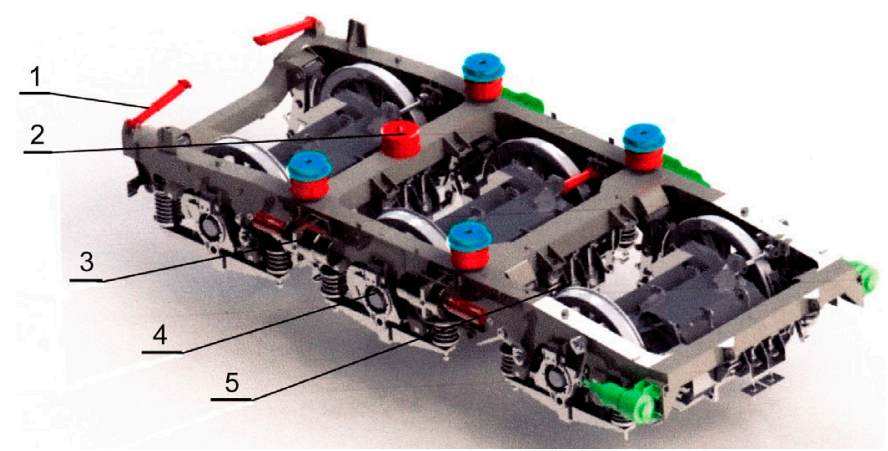

Rys.6 - Ogólne rozmieszczenie głównych podzespołów wózka lokomotywy ST46 (303Da) zmienionych w ramach modernizacji: 1- thumiki hydrauliczne; 2- piąta podpora elastyczna; 3- hamulec sprężynowy; 4- przesuwna oś środkowa.; 5- smarowanie obrzeży kół

- urządzenia bezpieczeństwa ruchu w tym układ samoczynnego hamowania pociagu LZB/PZB stosowany na DB (kolejach niemieckich)

- dualne urządzenia radiołączności (łączność analogowa oraz GSM-R) wyposażone w moduły zgodnie $\mathrm{z}$ wymaganiami kolei polskich i niemieckich oraz spełniające wymagania w zakresie interoperacyjności dla kolei konwencjonalnych

- kabiny sterownicze zapewniające pełne bezpieczeństwo dla obsługi dwuosobowej wyposażone w:

- nowoczesne pulpity sterowniczy i pomocniczy

- nowoczesne fotele spełniające wymagania ergonomii i zapewniające możliwość szybkiej ewakuacji

- kamery boczne umożliwiające obserwację do tyłu z obu stron lokomotywy

- układy klimatyzacji (schładzanie) oraz ogrzewanie

- płytę grzewczą zabudowaną na pulpicie pomocnika

- oświetlenie wnętrza z możliwością regulacji jego natężenia

- szafkę odzieżową, umywalkę oraz szafkę narzędziową 

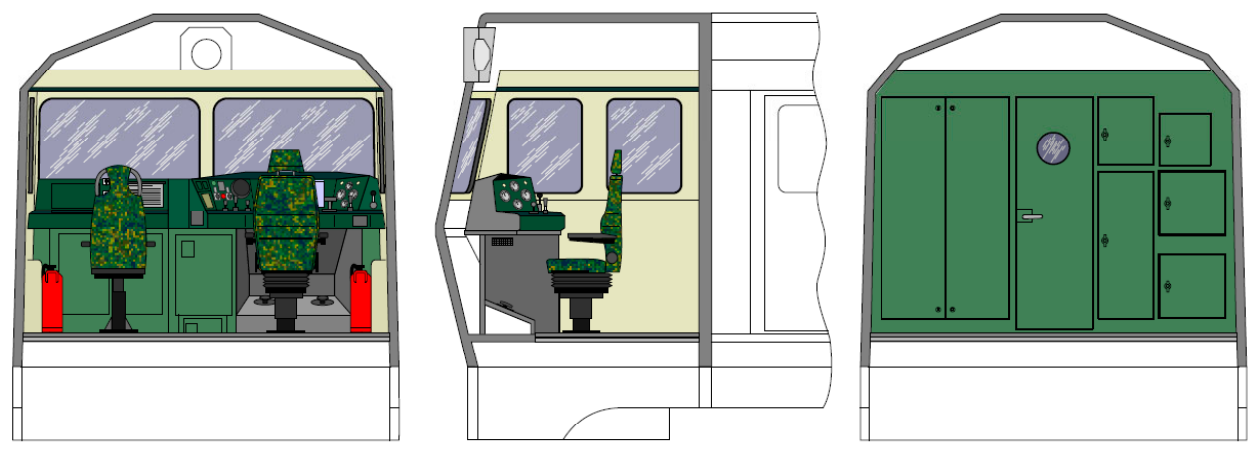

Rys. 7 - Projekt wnętrza kabiny maszynisty lokomotywy spalinowej ST46 (303Da)

- nową izolację akustyczną i termiczną gwarantującą tłumienie dźwięku i zapewniająca właściwy komfort cieplny

- nowe wyłożenia wykonane $\mathrm{z}$ płyt poliwęglowych i laminatów poliestrowoszkla-nych

- układ wykrywania i sygnalizacji pożaru oraz stałą instalację gaszącą.

Propozycje wizualną kabiny sterowniczej zaakceptowana przez użytkownika zaprezentowano na rys. 7 .

\section{Podsumowanie}

Wykonana zmodernizowana lokomotywa spalinowa serii ST46 (303Da) zostanie skierowana w połowie bieżącego roku do prób i badań zgodnie $\mathrm{z}$ wymaganiami Rozporządzenia Ministra Infrastruktury (Dz. U. nr 212 z dnia 12.10.2005 poz. $1772 \S 4$ pkt. 1).

W szczególności zostaną wykonane następujące sprawdzenia, próby i badania:

- odbiorcze zgodnie z wymaganiami Warunków Technicznych Odbioru

- wyznaczenie charakterystyk trakcyjnych

- określenie bezpieczeństwa przed wykolejeniem oraz wyznaczenie oddziaływania dynamicznego lokomotywy na tor

- badania wpływu lokomotywy na pracę urządzeń srk oraz zakłóceń radioeletrycznych i elektromagnetyczych emitowanych do wnętrza i na zewnątrz lokomotywy

- badania układów hamulca, urządzeń przeciwpoślizgowych oraz urządzeń i układów związanych $z$ bezpieczeństwem ruchu

- ocena własności akustycznych

- ocena warunków pracy maszynistów (pomiary hałasu, oświetlenia, warunków komfortu i ergonomii oraz indukcyjności pola magnetycznego).

Po uzyskaniu pozytywnych wyników i terminowego świadectwa dopuszczenia do eksploatacji zmodernizowana lokomotywa zostanie skierowana do prób eksploatacyjnych tj. 12 miesięcznej normalnej eksploatacji z pociagami towarowymi.
W zakończeniu należy stwierdzić, że największe korzyści ze zmodernizowanych lokomotyw ST46 (303Da) osiagnięte zostaną tylko w przypadku wdrożenia do eksploatacji większej liczby lokomotyw.

Oczywistym jest, że efekty z przeprowadzonej modernizacji będą również widoczne dopiero po dłuższym okresie czasu, nie mniej jednak proces unowocześnienia parku lokomotyw spalinowych realizowanych przez zakupy nowych lokomotywa oraz przez modernizację winien być prowadzony, gdyż w przeciwnym razie może w niedługim czasie zabraknać na torach Polskich Linii Kolejowych nowoczesnych krajowych spalinowych pojazdów trakcyjnych.

\section{Literatura}

[1] Marciniak Z.: Modernizacja lokomotywy spalinowej typu M62 w oparciu o silnik 12CzN26/26 - konstrukcja $i$ wyniki badań. Technika Transportu Szynowego, 2007, nr 1i 2.

[2] Marciniak Z.: Modernizacja lokomotyw spalinowych - stan obecny i zamierzenia,. Materiaty XVIII Konferencji Naukowej „Pojazdy Szynowe”, Katowice Ustroń, 2008.

[3] Marciniak Z.: Doposażenie, remotoryzacja oraz modernizacja liniowych i manewrowych lokomotyw spalinowych w Pesa Bydgoszcz S.A., Technika

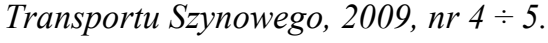

[4] Marciniak Z.: Polonizacja, remotoryzacja $i$ modernizacja lokomotyw spalinowych eksploatowanych $w$ kraju. Pojazdy Szynowe, 2010, nr 1.

[5] Marciniak Z.: Nowe rozwiqzania i układy w zmodernizowanej lokomotywie spalinowej typu 301Dd serii ST45 do ruchu towarowego. Materiaty XIX Konferencji Naukowej Pojazdy Szynowe, Targanice k/Andrychowa, 2010.

[6] Marciniak Z.: Projekty modernizacyjne spalinowych lokomotyw liniowych $i$ manewrowych wykonanych $w$ Instytucie Pojazdów Szynowych, Logistyka, 2010, nr 4.

[7] Michalak P., Bejenka K.: Specyfikacja techniczna zespołów wyposazeniowych lokomotywy ST46. Opracowanie niepublikowane - Pesa Bydgoszcz / IPS ,,Tabor” - Z1/1611/OR-9727, Bydgoszcz / Poznań 04.2010.

[8] Zakres modernizacji lokomotywy spalinowej serii SU46 (ze zmiana serii na ST46) Opracowanie niepublikowane PKP Cargo, 2009. 